\title{
Nilai Pendidikan Dalam film Alangkah Lucunya Negeri Ini
}

\author{
Ari Susanti* Ismam Asyari** \\ *Dosen Fisipol Unmuh Jember \\ **Alumnus Fisipol Unmuh Jember
}

\begin{abstract}
ABSTRAK
Film "Alangkah Lucunya (Negeri Ini)" adalah sebuah film karya Deddy Mizwar yang mencerminkan realitas social yang ada di dalam kehidupan masyarakat di negeri ini. Kelompok kami memilih film ini karena beberapa alasan, salah satu alasan pemilihan film ini sebagai analisis film yang akan dikaitkan dengan sistem komunikasi yang ada di Indonesia adalah karena di dalam film ini terkandung berbagai macam makna kehidupan mulai dari makna religi, nasionalisme, kehidupan sosial, serta pendidikan untuk memilih mana yang baik atau benar dan yang mana yang salah. Di era yang sudah berkembang seperti ini, menyampaikan nilai-nilai yang bermakna pendidikan bisa disampaikan melaui media-media yang sudah modern dimana cara penyampaiannya secara luas dengan waktu yang singkat seperti melalui internet, televisi, radio, koran dan lain-lain yang sifatnya media massa. Nilai pendidikan dikemas dengan cara yang menyenangkan melalui musik, film, pentas drama, dan lain-lain sehingga mampu diterima untuk berbagai kalangan dan berbagai umur. Peneliti menganalisa disetiap adegan yang mengandung unsur pendidikan dalam film "Alangkah Lucunya Negeri Ini" mulai dari pendidikan sosial, pendidikan agama, pendidikan poilitik dan lain sebagainya.
\end{abstract}

Kata Kunci : Realitas Social

\section{ABSTRACT}

The movie "Alangkah Lucunya (Negeri Ini)" is a film by Deddy Mizwar that reflect social realities that exist in the lives of people in this country. Our group chose this movie for several reasons, one of the reasons for the selection of this film as a film analysis that would be associated with existing communication systems in Indonesia is because in this film contained a wide range of meaning of life from the meaning of religion, nationalism, social life, as well as education to choose what is good or right and which is wrong. In an era that has developed like this, convey meaningful values education can be delivered through the media that has modern which delivery method widely with such a short time over the internet, television, radio, newspapers and other mass media nature . Educational value packed in a fun way through music, movies, stage plays, and others so that they can be accepted for various groups and various ages. Researchers analyzing each scene contains elements of education in the movie "Alangkah Lucunya Negeri Ini" ranging from social education, religious education, education poilitik and so forth.

Keywords: Social Realities 


\section{Pendahuluan}

Film "Alangkah Lucunya (Negeri Ini)" adalah sebuah film karya Deddy Mizwar yang mencerminkan realitas social yang ada di dalam kehidupan masyarakat di negeri ini. Kelompok kami memilih film ini karena beberapa alasan, salah satu alasan pemilihan film ini sebagai analisis film yang akan dikaitkan dengan sistem komunikasi yang ada di Indonesia adalah karena di dalam film ini terkandung berbagai macam makna kehidupan mulai dari makna religi, nasionalisme, kehidupan sosial, serta pendidikan untuk memilih mana yang baik atau benar dan yang mana yang salah.

Film ini mengulas dengan detail kondisi yang terjadi pada negara ini. Kondisi tersebut benar-benar menyentuh bangsa ini seperti masalah pengganguran, kimiskinan, tempat tinggal yang tidak layak, dan masalah pendidikan. Masalah penggangguran dan kemiskinan digambarkan dalam film ini melalui peran seorang sarjana managemen yang bernama Muluk (Reza Rahadian) yang sedang mondar-mandir keluar masuk perusahaan untuk mencari pekerjaan, bersama Syamsul (Asrul Dahlan) seorang sarjana pendidikan yang setiap harinya menggangur bermain kartu serta adik perempuan muluk yaitu Pipit (Tika Bravani) seorang penggaguran yang setiap harinya ia habiskan dengan mengikuti kuis di televisi. Sampai pada suatu saat, ketiga orang tersebut terpaksa bekerja bersama para pencopet untuk memenuhi kebutuhan hidupnya. Kondisi tempat tinggal dan pendidikan yang tidak layak kode-kode musik, 9) bahasa yang diformalkan, 10) bahasa tertulis, alfabert tak dikenal, kode teori teks, 16) kode-kode budaya, 17) teks juga diulas dalam film ini misalnya seorang anak-anak karena keterbatasan biaya mereka tidak bisa memperoleh pendidikan secara layak yang akhirnya sekelompok anak-anak tersebut memilih menjadi seorang pencopet dan hidup secara liar di sebuah bangunan kumuh. Sedangkan masalah dalam penelitian ini adalah;" Bagaimanakah nilai-nilai pendidikan dalam film Alangkah Lucunya Negeri Ini?”

\section{Tinjauan Pustaka}

Dalam kutipan buku "Semiotika Komunikasi” buku $A$ Theory of Semiotics, Eco (1979) menyebutkan bahwa suatu penelitian semiotika umum akan dihadapkan pada berbagai batas bidang kajian. Beberapa di antaranya harus disepakati sementara, sedangkan lainnya menurut Eco, ditentukan oleh objek disiplin ilmu itu sendiri. Dalan buku ini, Eco mengemukakan tiga batas sehubungan dengan penelitan semiotika yaitu "ranah budaya", "ranah alam", dan "ranah epistemologis".

Bidang semiotika memang boleh dikata begitu luas. Bidang ini bisa berupa proses komunikatis yang tampak lebih "alamiah" dan spontan sampai pada sistem budaya yang lebih kompleks. Dalam kaitan, Eco (1979:9-14) menyebut tidak kurang dari 19 bidang yang bisa dipertimbangkan sebagai bahab kajian semiotika, yaitu : 1) semiotika binatang, 2) tanda-tanda bauan, 3) komunikasi rabaan, 4) kode-kode cecapan, 5) paralinguitik, 6) semiotika medis, 7) kinesik dan proksemik, 8)

rahasia, 11) bahasa alam, 12) komunikasi visual, 13) sistem objek, 14) struktur alur, 15) estetik, 18) komunikasi massa, dan 19) retorika. 
Bidang terapan semiotika pada komunikasi tidaklah terbatas. Misalnya bisa mengambil objek penelitian mulai dari pemberitaan media massa, komunikasi periklanan, tanda-tanda nonverbal, film, komik-kartun, sastra, sampai kepada musik. Ada beberapa bidang terapan semiotika menurut Alex Sobur (2006: 110-144), antara lain:

1) Media

Pada dasarnya, studi media massa mencakup pencarian pesan dan makna-makna dalam materinya, karena sesungguhnya semiotika komunikasi, seperti halnya basis studi komunikasi, adalah proses komunikasi, dan intinya adalah makna. Dengan kata lain, mempelajari media adalah mempelajari makna - darimana asalnya, seperti apa, seberapa jauh tujuannya, bagaimanakah ia berkaitan dengan pemikiran kita sendiri. Maka itu, metode penelitian dalam komunikasi semestinya mampu mengungkapkan makna yang terkandung dalam materi pesan komunikasi.

2) Komunikasi Periklanan

Untuk mengkaji iklan dalam perspektif semiotika, kita bisa mengkajinya lewat sistem tanda dalam iklan. Iklan menggunakan sistem tanda yang terdiri atas lambang, baik yang verbal maupun yang berupa ikon. Iklan juga menggunakan tiruan indeks, terutama dalam iklan radio, televisi, dan film.

3) Tanda Nonverbal

Dalam hal pengaplikasian semiotika pada tanda nonverbal, yang terutama penting diperhatikan adalah pemahaman tentang bidang nonverbal. Bidang nonverbal adalah suatu

6) Sastra wilayah yang menekankan pentingnya fenomena yang bersifat empiris, faktual, atau konkret, tanpa ujaran-ujaran bahasa. Ini berarti bidang nonverbal berkaitan dengan benda kokret, nyata, dan dapat dibuktikan melalui indera manusia.

4) Film

Film umumnya dibangun dengan banyak tanda. Tanda-tanda itu termasuk berbagai sistem tanda yang berkerja sama dengan baik dalam upaya mencapai efek yang diharapkan. Yang paling penting dalam film adalah gambar dan suara: kata yang diucapkan (ditambah dengan suara-suara lain yang serentak mengiringi gambar-gambar) dan musik film. Sistem semiotika yang lebih penting lagi dalam film adalah digunakannya tanda-tanda ikonis, yakni tanda-tanda yang menggambarkan sesuatu.

5) Komik-Kartun-Karikatur

Dalam menganalisis kartun atau komikkartun, kita seyogyanya menempatkan diri sebagai kritikus, agar bisa secara leluasa melakukan penilaian dan memberi tafsiran terhadap komik-kartun tersebut. Melihat entitas tanda-tanda visual dalam komik, dapat dianggap sebagai "teks" yang berdiri sendiri. Untuk itu telaah simbolik (hermeneutik) bisa diterapkan sebagai alat bantu penelusuran makna tanda dalam "teks" tersebut. Akan tetapi, guna mempertajam interpretasi makna serta menjaga validitas kajian, diperlukan data yang berfungsi sebagai penguat tafsiran. 
Dalam lapangan sastra, karya sastra dengan keutuhannya secara semiotik dapat dipandang sebagai sebuah tanda. sebagai suatu bentuk, karya sastra secara tertulis akan memiliki sifat kerungan. Dimensi ruang dan waktu dalam sebuah cerita rekaan mengandung tabiat tanda-menanda yang menyiratkan makna semiotika (atau tataran kebahasaan dan mistis) sebuah karya saatra menemukan keutuhannya untuk dipahami dan dihayati.

\section{7) Musik}

Apa yang bisa kita kaji pada musik? Sistem tanda musik adalah oditif. Namun, untuk mencapai pendengarnya, penggubah musik mempersembahkan kreasinya dengan perantara pemain musik dalam bentuk sistem tanda perantara tertulis, jadi visual. Bagi semiotikus musik, adanya tanda-tanda perantara, yakni, musik yang dicatat dalam partitur orkestra, merupakan jalan keluar. Hal ini sangat memudahkan dalam menganalisis karya musik sebagai teks. Itulah sebabnya mengapa penelitian musik semula terutama terarah pada sintaksis. Meski demikian, semiotika tidak dapat hidup hanya dengan mengandalkan sintaksis: tidak ada semiotika tanpa semantik. Jadi, juga tidak ada semiotika musik tanpa semantik musik. Semantik musik, bisa dikatakan, harus senantiasa membuktikan hak kehadirannya.

\section{Metode Penelitian}

Jenis penelitian yang dipergunakan oleh penulis untuk penyusunan skripsi ini adalah penelitian deskriptif kualitatif. Metode penelitian kualitatif adalah prosedur penelitian yang menghasilkan data deskriptif berupa kata-

Dalam pengumpulan data tersebut, kata tertulis atau lisan dari orang-orang dan perilaku yang dapat diamati. Metode deskriptif bertujuan melukiskan secara sistematis fakta atau karakteristik populasi tertentu secara faktual dan cermat. (Isaac dan Michael dalam Rakhmad, $1991: 22$ ).

Objek kajian dalam penelitian ini adalah makna nilai-nilai pendidikan dalam Film Alangkah Lucunya Negeri ini melalui pendekatan semiotika nilai-nilai pendidikan. Untuk membahas hal tersebut, penulis melakukan kajian film Alangkah Lucunya Negeri ini secara mendalam.

Sumber data dalam penelitian ini meliputi 2 (dua) sumber data, yaitu data primer dan data sekunder :

\section{Data Primer}

Data primer adalah data yang diperoleh langsung dari obyek penelitian melalui cara pengamatan langsung terhadap obyek penelitian yaitu dengan menyaksikan secara langsung Film Alangkah Lucunya Negeri Ini melalui media DVD.

2. Data Sekunder

Data Sekunder adalah data yang berasal dari sumber-sumber lain yang sekiranya dapat mendukung penelitian. Data tersebut diperoleh dari sumber-sumber lain yang sudah dikumpulkan dari berbagai pihak, yaitu dari buku-buku dan literatur-literatur yang membahas tentang musik serta menunjang penelitian.

Metode Pengumpulan Data adalah suatu tekhnik atau cara yang dilakukan oleh peneliti dalam memperoleh data atau informasi yang digunakan sebagai bahan penelitian. penulis akan melakukan dengan menggunakan 
metode kualitatif. Selain itu metode penelitian dilakukan dengan melakukan pengamatan (observasi). "Metode observasi adalah metode pengumpulan data yang digunakan untuk menghimpun data penelitian, data penelitian tersebut dapat diamati oleh peneliti. Dalam arti bahwa data tersebut dihimpun melalui pengamatan peneliti melalui penggunaan pancaindra. Dengan metode pengumpulan data ini, peneliti akan mengamati langsung bagaimana atau seperti apa masalah yang berkaitan dengan penelitian.

Pengumpulan data primer dilakukan dengan menyaksikan secara langsung Film Alangkah Lucunya Negeri Ini secara berulangulang untuk mengapresiasi dan memahami semiotika makna nilai-nilai pendidikan yang ada di dalam film tersebut. Pengumpulan data sekunder dilakukan dengan melakukan studi pustaka adalah suatu teknik pengumpulan data dengan mencari informasi dari data pustaka yang bisa mendukung penelitian. Data yang diperoleh dari berbagai referensi buku, jurnal, dan karya ilmiah serta data-data lain yang berhubungan dengan penelitian ini. Dalam penelitian ini, studi kepustakaan sangat dibutuhkan karena melalui teknik ini peneliti dapat memperkuat penjelasan dalam memberikan penafsiran.

Teknik analisis data yang dipergunakan adalah analisis terhadap film Alangkah Lucunya Negeri Ini melalui pendekatan semiotika nilai-nilai pendidikan. Dalam penelitian ini, analisis film akan dilakukan dengan membagi keseluruhan film menjadi beberapa dialog dalam film Alangkah Lucunya
Negeri Ini akan dianalisis dengan menggunakan teori Saussure dan teori makna.

Teori semiotika yang akan digunakan adalah teori milik Saussure, seorang ahli linguistik yang amat tertarik pada bahasa. Dia lebih memperhatikan cara tanda-tanda (atau dalam hal ini, kata-kata) terkait dengan tandatanda lain dan bukannya cara tanda-tanda terkait dengan objek. Jadi model dasar Saussure lebih memfokuskan perhatian langsung pada tanda itu sendiri. Dalam penelitian film Alangkah Lucunya Negeri Ini, peneliti akan membuat bagian berdasarkan teori semiotika Saussure dimana terdapat signifier, signified, dan signifikasi. Tanda merupakan kombinasi dari konsep kata-kata yang tidak dapat dipisahkan dalam sebuah gambar. Dialog yang ada dalam film merupakan konsep tanda atau lambang yang mempunyai makna tertentu. Tahapan analisis data penelitiannya adalah sebagai berikut :

a) Mengapresiasikan obyek penelitian, sebagai langkah awal dalam memahami dialog film secara awam yaitu dengan mengikuti alur cerita dalam film secara fokus sehingga mengerti pesan apa yang ingin disampaikan oleh sutradara film kepada penonton.

b) Membedah objek penelitian dalam hal ini adalah dialog film secara keseluruhan menjadi beberapa dialog untuk mencermati tanda-tanda mana yang digunakan sutradara dalam menyampaikan pesan pada objek penelitian. Ini dilakukan dengan mengartikan simbol-simbol yang mewakili pesan yang ingin disampaikan 
oleh sang sutradara tersebut kepada penonton.

c) Menafsirkan arti tanda-tanda tersebut dari sudut pandang peneliti dengan analisis semiotika yang mengungkap signifier, signified dan signification.

d) Mengkombinasikan temuan-temuan tandatanda tersebut dengan menganalisis dengan situasi dan kondisi sosial latar belakang dalam film tersebut.

e) Menarik kesimpulan berdasarkan atas analisis yang dilakukan pada tahap-tahap analisis sebelumnya.

Sesuai dengan tipe penelitian kualitatif, maka data yang terkumpul dianalisis secara kualitatif. Dalam arti gejala yang muncul secara keterkaitan diungkapkan secara lebih mendalam dan terperinci dengan menggunakan deskripsi kualitatif secara sistematis. Untuk menganalisis data-data yang diperoleh maka penulis menggunakan metode analisis data kualitatif yaitu setiap gejala yang muncul serta berbagai keterkaitan antar gejala diungkapkan secara lebih mendalam dan terperinci. Bagi pendekatan kualitatif, analisis data secara kasar telah dilakukan dalam proses pengumpulan data.

\section{Pembahasan}

\section{Sinopsi Film "Alangkah Lucunya Negeri Ini”}

Film “Alangkah Lucunya Negeri Ini” menceritakan seorang anak muda lulusan S1 Managemen yang bernama Muluk sebagai seorang yang baru saja lulus kuliah, tentu saja berupaya untuk mencari kerja. Dengan berbekal ijazah yang dimiliki serta surat kabar yang memuat berbagai lowongan kerja, namun semua lamaran tersebut tidak membuahkan hasil.

Semangat Muluk dalam mencari kerja tidak pernah berhenti dan akhirnya melihat sekelompok anak yang melakukan aksi copet di sebuah pasar. Dengan geram Muluk meringkus anak tersebut dan mengancam melaporkannya kepada polisi. Beberapa waktu kemudian, di sebuah warung Muluk bertemu dengan Komet. Komet akhirnya membawa Muluk ke markasnya dan memperkenalkan dengan Jarot yang menjadi pemimpin para pencopet. Di sisi lain, ayah Muluk yang bernama Pak Makbul berdebat serius dengan Haji Sarbini yang merupakan calon besannya. Muluk akan dijodohkan dengan Rahma. Keduanya terus saja berdebat walaupun berusaha dilerai oleh Haji Rahmat, seorang tetua dalam bidang agama Islam di daerah tersebut.

Perkenalan Muluk dan Jarot menghasilkan kesepakatan bahwa Muluk akan bekerja bersama dengan para pencopet tersebut untuk mempraktekkan ilmu manajemen yang dimiliki dengan mengelola keuangan mereka. Ini ditawarkan oleh Muluk dengan imbalan $10 \%$ dari hasil copet mereka. Tujuan Muluk adalah agar hasil copet mereka dapat dikelola secara profesional dan akhirnya dapat dijadikan sebagai modal usaha agar tidak perlu menjadi pencopet lagi. Secara umum, kelompok pencopet ini dibagi menjadi 3, yaitu kelompok mall yang terdiri atas pencopet yang berpakaian paling bagus dan "gaul”, kelompok pasar yang berpakaian paling kumal, dan kelompok angkot yang berpakaian sekolah. Setiap kelompok memiliki pemimpin dan 
metode kerja sendiri-sendiri. Muluk pun menyadari bahwa anak-anak ini juga butuh pendidikan, dan untuk mengajar mereka, Muluk meminta bantuan Samsul, seorang Sarjana Pendidikan pengangguran yang seharihari hanya bermain kartu saja agar mempraktikan apa yang telah diperoleh dari kuliahnya dulu.

Sebuah permasalahan kecil terjadi saat ayah Muluk bertanya mengenai pekerjaannya. Dengan terpaksa Muluk menjawab bahwa pekerjaannya adalah di bagian Pengembangan Sumber Daya Manusia. Beberapa waktu kemudian, Haji Rahmat meminta Muluk agar dapat mempekerjakan anaknya, Pipit, karena sehari-hari Pipit hanya mengurusi kuis-kuis di televisi dan mengirim undian berhadiah kemana-mana. Muluk-pun menyanggupi hal tersebut dan mengajak Pipit untuk mengajar agama bagi anak-anak pencopet.

Rasa penasaran pun muncul dari Pak Makbul ayah Muluk, Haji Rahmat ayah Pipit, dan Haji Sarbini calon mertua Muluk. Mereka pun bersikeras hendak melihat tempat kerja Pipit, Muluk dan Samsul. Mereka amat terkejut sewaktu mengetahui bahwa anak-anak mereka rupanya bekerja untuk para pencopet .

Pertentangan batin yang hebat segera terjadi di hati mereka yang juga mempengaruhi Muluk, Pipit, dan Samsul. Mereka akhirnya berhenti mengajari anak-anak itu. Setalah itu, Jarot memberikan pengarahan kepada anakanak itu tentang bagaimana mereka seharusnya mencari uang dengan uang halal. Golongan copet pasar akhirnya sadar dan mereka berubah profesi menjadi pedagang asongan, golongan mall dan angkot tetap pada profesi mereka yaitu pencopet. Namun, saat golongan copet pasar sedang berdagang di jalan raya tiba-tiba ada satpot pp yang menertibkan jalanan tersebut. Anak-anak banyak yang tertangkap tetapi pada saat itu. Muluk melihat kejadian itu dan mengaku kepada satpol pp bahwa dia adalah orang yang menyuruh anak-anak itu mengasong (bos mereka). Sehingga, Muluk pun dibawa pergi oleh satpol pp tersebut.

Nilai-nilai Pendidikan dalam film

“Alangkah Lucunya Negeri Ini”

Di era yang sudah berkembang seperti ini, menyampaikan nilai-nilai yang bermakna pendidikan bisa disampaikan melaui mediamedia yang sudah modern dimana cara penyampaiannya secara luas dengan waktu yang singkat seperti melalui internet, televisi, radio, koran dan lain-lain yang sifatnya media massa. Nilai pendidikan dikemas dengan cara yang menyenangkan melalui musik, film, pentas drama, dan lain-lain sehingga mampu diterima untuk berbagai kalangan dan berbagai umur. Peneliti menganalisa disetiap adegan yang mengandung unsur pendidikan dalam film “Alangkah Lucunya Negeri Ini” mulai dari pendidikan sosial, pendidikan agama, pendidikan poilitik dan lain sebagainya.

\section{Scene ke-1}

Adegan pertama yang dipilih peneliti adalah ketika Muluk berjalan dibawah terik matahari kota jakarta untuk melamar pekerjaan setelah menyelesaikan sekolah perguruan tingginya dan muluk mendapatkan gelar sarjana menejem. Tetapi sudah beberapa perusahan dimasuki, Muluk hanya mendapat penolakan. Muluk tidak pantang menyerah dan 
tetap berusaha untuk mendapat pekerjaan yang

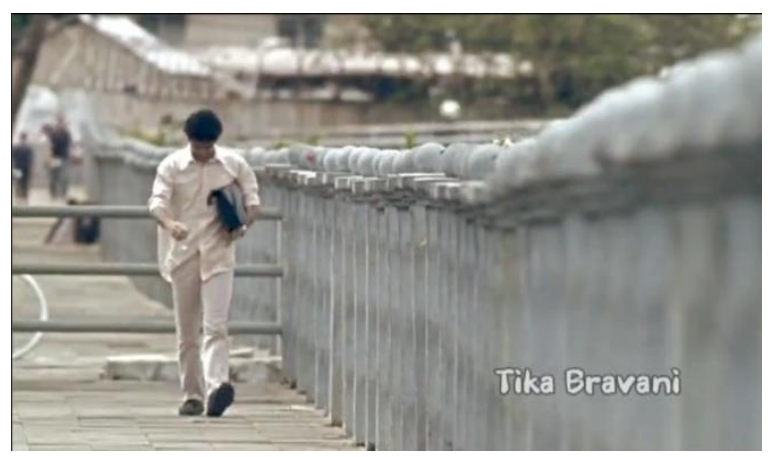

\section{Gambar 1}

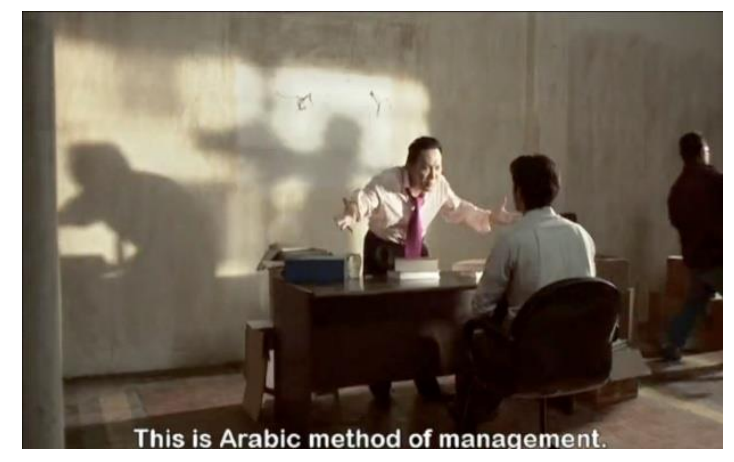

Gambar 3

\section{Gambar 5}

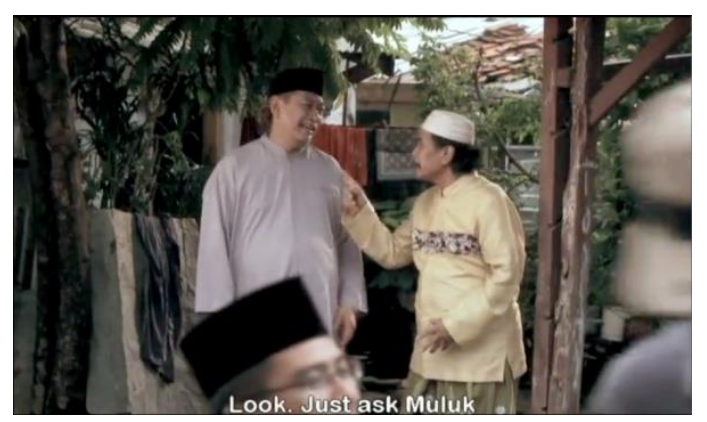

sesuai dengan ijazah terakhir muluk.

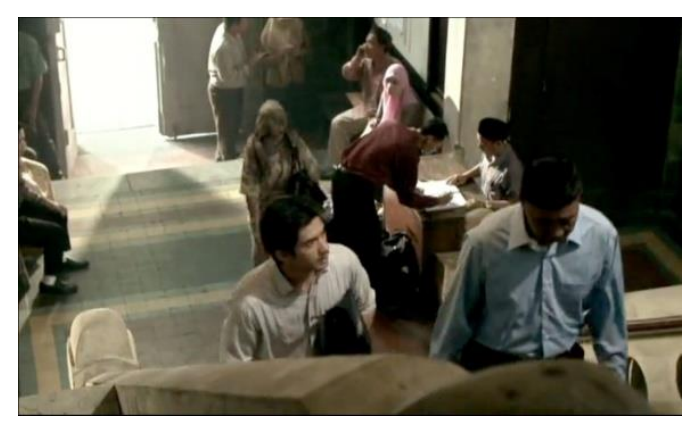

\section{Gambar 2}

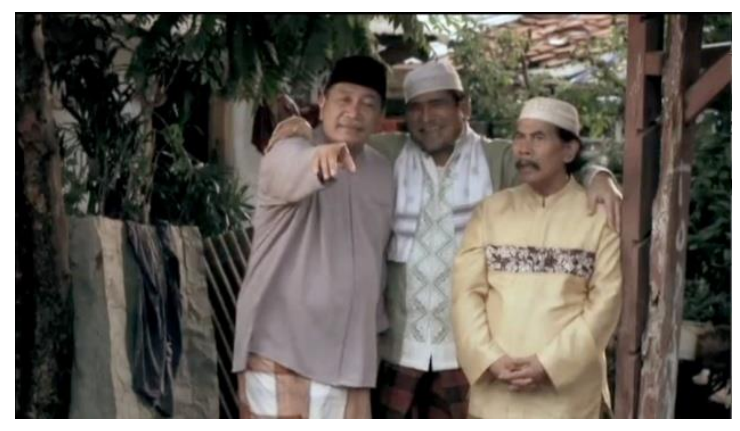

Gambar 4

\section{Gambar 6}

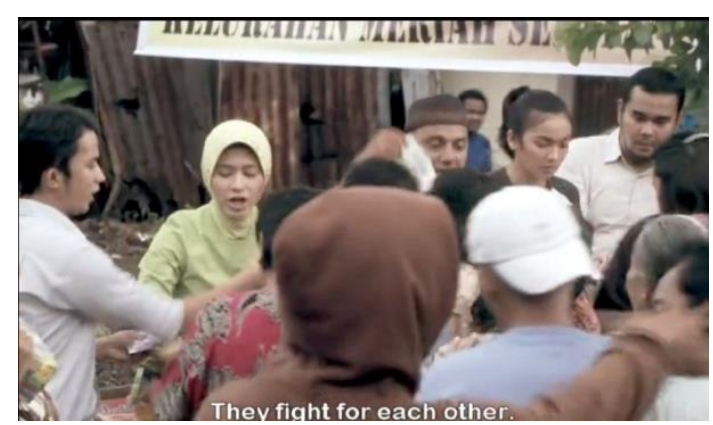

\begin{tabular}{|l|l|l|l|}
\hline No & Visual & Dialog & Type of Shot \\
\hline 1 & Gambar 1 & (tanpa dialog) & $\begin{array}{l}\text { Long shot, pengambilan } \\
\text { secara keseluruhan, gambar } \\
\end{array}$ \\
Menit ke 03.27 & & $\begin{array}{l}\text { diambil dari jarak jauh, } \\
\text { seluruh objek terkena hingga } \\
\text { latar belakang objek }\end{array}$ \\
\hline
\end{tabular}




\begin{tabular}{|c|c|c|c|}
\hline 2 & $\begin{array}{l}\text { Gambar } 2 \\
\text { Menit ke } 04.35\end{array}$ & $\begin{array}{l}\text { Pemilik perusahaan : "saudra } \\
\text { Muluk, ilmu apa yang anda } \\
\text { punya" } \\
\text { Muluk : "ilmu menejmen pak". } \\
\text { Pemilik peruhaan "segala ilmu } \\
\text { sudah saya terapkan termasuk } \\
\text { ilmu yang kamu punya, tapi } \\
\text { tidak bisa menyelamatkan } \\
\text { perusahaan ini" }\end{array}$ & $\begin{array}{l}\text { Medium long shot, di ambil } \\
\text { dari jarak yang wajar, } \\
\text { sehingga jika misalnya } \\
\text { terdapat tiga objek maka } \\
\text { seluruhnya akan terlihat. Bila } \\
\text { objeknya } 1 \text { orang maka } \\
\text { tampak dari kepala hingga } \\
\text { lutut }\end{array}$ \\
\hline 3 & $\begin{array}{l}\text { Gambar } 3 \\
\text { Menit ke } 05.15\end{array}$ & $\begin{array}{l}\text { "pekerja disini sudah penuh } \\
\text { pak" pemilik perusahan yang } \\
\text { lain menjelaskan sambil jalan } \\
\text { berlalu meninggalkan muluk }\end{array}$ & $\begin{array}{l}\text { Long shot, pengambilan } \\
\text { secara keseluruhan, gambar } \\
\text { diambil dari jarak jauh, } \\
\text { seluruh objek terkena hingga } \\
\text { latar belakang objek }\end{array}$ \\
\hline
\end{tabular}

\begin{tabular}{|c|c|}
\hline Denotasi & $\begin{array}{l}\text { Gambar 1: terlihat Muluk yang berjalan menyusuri panasnya kota } \\
\text { jakarta } \\
\text { Gambar 2: pemilik perusahaan seperti meremehkan ilmu yang } \\
\text { dimiliki Muluk dan Muluk hanyak diam pasrah tanpa perlawanan. } \\
\text { Gambar 3: Muluk mendapatkan penolakan lagi dari sebuah pemilik } \\
\text { agen TKI (Tenaga Kerja Indonesia) }\end{array}$ \\
\hline Konotasi & $\begin{array}{l}\text { Gambar 1: Konotasi yang ingin disampaikan dari gambar ini adalah } \\
\text { perjuangan seorang sarjana yang pantang menyerah untuk } \\
\text { mendapatkan kerja. } \\
\text { Gambar 2: pada gambar ini menjelaskan ilmu kuhusus yang di dapat } \\
\text { mahasiswa seakan tak dapat menolong perusahaan yang hampir } \\
\text { bangkrut. } \\
\text { Gambar 3: disini terlihat, pemilik perusahaan yang lain tidak peduli } \\
\text { Muluk adalah seorang sarjana. Jika perusahaan itu sudah penuh } \\
\text { artinya sudah tidak ada lowongan lagi. }\end{array}$ \\
\hline
\end{tabular}

\begin{tabular}{|l|l|}
\hline & Gambar 1: Seperti yang sering didengar, berakit-rakit kehulu \\
& berenang ketepian. Tidak ada usaha yang sia-sia, jika terus bersaha \\
& semua pasti bisa mencapai kesuksesan dan keberhasilan. Selain itu \\
jilai Pendidikan & $\begin{array}{l}\text { jangan pernah mengeluh dengan keadaan. } \\
\text { menjaga bagaimana mempertahankan sesuatu itu agar tetap bertahan. } \\
\text { Bukan hanya mempelajari ilmu menejmen saja tetapi bagaimana cara } \\
\text { menerapkan strategi ilmu dengan baik dan benar. }\end{array}$ \\
\hline
\end{tabular}




\begin{tabular}{|l|l|}
\hline Gambar 3: di tolak bukan berarti berhenti berusaha. Ditolak itu \\
artinya kita harus tetap berjuang untuk pekerjaan yang lebih baik dan \\
bisa jadi menciptakan lapang kerja sendiri. Karena Allah telah \\
memberikan akal kepada setiap manusia jadi Allah menguji seseorang \\
untuk memanfaatkan akal yang sudah diberikan dengan seberapa \\
banyak ilmu yang sudah didapat dari seseorang itu sendiri.
\end{tabular}

\section{Scene ke-2}

Pada saat Muluk sedang giatgiatnya mencari kerja, ada perbedaan pendapat antara haji Sarbini calon mertua muluk dan pak bul ayah Muluk. Kontek pendidikan dan pendidikan menjadi perdebatan yang selalu dibahas diantara mereka.

\begin{tabular}{|c|c|c|c|}
\hline No & Visual & Dialog & Type of Shot \\
\hline 1 & $\begin{array}{l}\text { Gambar } 4 \\
\text { Menit ke } 07.07\end{array}$ & $\begin{array}{l}\text { Haji Sarbini : "penididikan } \\
\text { itu tidak penting pak Bul. } \\
\text { Anak saya yang pertama } \\
\text { lulusan SMA sekarang sudah } \\
\text { punya toko yang besar dan } \\
\text { sudah mau naik haji, terus } \\
\text { anak saya yang kedua lulusan } \\
\text { SMP sekarang sudah punya } \\
\text { usaha sablon yang besar. } \\
\text { jaman sekarang banyak sarnya } \\
\text { yang stres gara-gara nganggur } \\
\text { " }\end{array}$ & $\begin{array}{l}\text { Medium long shot, di ambil dari } \\
\text { jarak yang wajar, sehingga jika } \\
\text { misalnya terdapat tiga objek } \\
\text { maka seluruhnya akan terlihat. } \\
\text { Bila objeknya } 1 \text { orang maka } \\
\text { tampak dari kepala hingga lutut }\end{array}$ \\
\hline 2 & $\begin{array}{l}\text { Gambar } 5 \\
\text { Menit ke } 07.21\end{array}$ & $\begin{array}{l}\text { Pak Makbul : "pendidikan } \\
\text { itu penting. Jepang, eropa, dan } \\
\text { amerika maju karena } \\
\text { pendidikan. Sekarang haji } \\
\text { Sarbini lihat antrian itu" pak } \\
\text { Bul menunjuk antrian yang } \\
\text { acak-acakan dan saling } \\
\text { berebut sumbangan sembako } \\
\text { "itu karena mereka tidak } \\
\text { berpendidikan" }\end{array}$ & $\begin{array}{l}\text { Medium long shot, di ambil dari } \\
\text { jarak yang wajar, sehingga jika } \\
\text { misalnya terdapat tiga objek } \\
\text { maka seluruhnya akan terlihat. } \\
\text { Bila objeknya } 1 \text { orang maka } \\
\text { tampak dari kepala hingga lutut }\end{array}$ \\
\hline
\end{tabular}




\begin{tabular}{|l|l|l|l|}
\hline 3 & Gambar 6 & (tanpa dialog) & $\begin{array}{l}\text { Long shot, pengambilan secara } \\
\text { keseluruhan, gambar diambil } \\
\end{array}$ \\
& Menit ke 07.48 & & $\begin{array}{l}\text { dari jarak jauh, seluruh objek } \\
\text { terkena hingga latar belakang } \\
\text { objek }\end{array}$ \\
\hline
\end{tabular}

\begin{tabular}{|c|c|}
\hline Denotasi & $\begin{array}{l}\text { Gambar 4: terlihat Haji sarbini kukuh dengan prinsipnya } \\
\text { bahwa pendidikan itu tidak penting jika tidak ada koneksi. } \\
\text { Gambar 5: pak Makbul menjelaskan bahwa pendidikan itu } \\
\text { penting karena tingkah laku seseorang akan terlihat jika orang } \\
\text { itu berpendidikan. } \\
\text { Gambar 6: menjelaskan kerumunan antrian yang tidak } \\
\text { beraturan saat pengambilan sumbangan sembako. }\end{array}$ \\
\hline Konotasi & $\begin{array}{l}\text { Gambar 4: Konotasi yang ingin disampaikan adalah masih } \\
\text { banyak orang yang meremehkan pendidikan. Orang yang } \\
\text { sekolah hanya membuang-buang waktu dan beranggapan lebih } \\
\text { enak mencari uang yang lebih menguntukan. } \\
\text { Gambar 5: Tetapi juga ada sebagian lagi menganggap bahwa } \\
\text { mencari ilmu itu memang sudah menjadi kewajiban bagi umat } \\
\text { manusia agar lebih banyak pengetahuannya dan bermanfaat } \\
\text { bagi diri sendiri juga bagi orang lain. }\end{array}$ \\
\hline Nilai Pendidikan & $\begin{array}{l}\text { Gambar 4: Ada perbedaan pemahaman dalam pendidikan. } \\
\text { Bagi sebagian orang pendidikan tinggi itu tidaklah berguna jika } \\
\text { tidak mendapat pekerjaan, dibandingkan seseorang yang hanya } \\
\text { sekolah sampai tamatan SMP/SMA tapi sudah mampu } \\
\text { mengahsilkan pekerjaan sendiri dan masih berpengang pada } \\
\text { prinsip "percuma perempuan sekolah tinggi kalau ujung- } \\
\text { ujungnya di dapur". } \\
\text { Gambar 5: Bagi sebagian orang lainnya pendidikan itu penting } \\
\text { karena dapat memiliki banyak pengetahuan, bertutur kata yang } \\
\text { baik, dan bertingkah laku yang sopan. } \\
\text { Gambar 6: manusia yang berpendidikan bisa dilihat dari } \\
\text { bagaimana mereka dapat mengantri dengan benar tanpa saling } \\
\text { mendahului. }\end{array}$ \\
\hline
\end{tabular}

\section{Kesimpulan}


Banyak hal yang didapat dari film Alangkah Lucunya Negeri ini mulai dari pesan pendidikan, agama, rasa nasionalisme, dan bersosialisasi. Ketika

mulai mengenal huruf, membaca hingga berhitung yang sebelumnya mereka sama sekali tidak dapat membaca, menulis, dan berhitung. Pengetahuan agama juga penting bagi anak-anak jalanan agar mereka tidak terjerumus kedalam kesesatan. Karena ilmu umum tanpa ilmu agama akan membuat manusia bekerja untuk duniawi tanpa memikirkan kelak di akhirat. Ilmu agama juga mengajarkan mana yang harus dilakukan dan mana yang tidak boleh
Muluk dan kedua temannya masuk dalam kehidupan para pencopet, kehidupan anakanak copet itu mulai berubah seperti :para pencopet yang masih diusia anak-anak

dilakukan. Muluk memang belum mendapatkan pekerjaan dengan ijazahnya tapi Muluk dapat menggunakan Ilmu manejennya untuk menerapkan hasil yang diperoleh pencopet untuk dikelolah agar terkumpul dan hasilnya di jadikan usaha yang lebih baik dan halal. Sebelum bertemu Muluk para pencopet belum perna sekalipun mengumpulkan uang hasil copetannya dalam jumlah yang banyak. 


\section{DAFTAR PUSTAKA}

Ardianto, Elvinano dan komala, lukiati. 2007. Komunikasi massa suatu pengantar. Bandung : Simbiosa Rekatama Media

Bignell, Jonathan. 1997. An Introduction Manchester and New York : Manchester University

Danesi, Marcel. 2010. Pengantar Memahami Semiotika Media. Yogyakarta: Jalasutra.

Irwansyah, Ade. 2009. Seandainya Saya Kritikus Film, Pengantar Menulis Kritik Film. Yogyakarta : homerian Pustaka

Kriyantono, Rachmat. 2006. Teknis Praktis Riset Komunikasi. Jakarta : Kencana

Kuswinarno, Engkus. 2009. Metodologi Penelitian Komunikasi : Fenomonologi. Bandung : Widya Padjajaran.

Moleong, Lexy J. 2006. Metode Penelitian Kualitatif. Bandung : Remaja Rosdakarya

Moleong, Lexy J. 2007.Metode Penelitian Kualitatif. Bandung : Remaja Rosdakarya

Mulyana, Deddy. 2005, Ilmu Komunikasi: Suatu Pengantar, Bandung, Remaja Rosdakarya.

Mulyana, Deddy. 2004. Metodologi Penelitian Kualitatif. Bandung: PT Remaja Rosdakarya.

Onong Effendy, 1994, Ilmu Komunikasi: Teori dan Praktek, Bandung, Remaja Rosdakarya

Prastista, Himawan. 2008. Memahami Film. Yogyakarta : Homerian Pustaka 
Sobur, Alex. 2004. Semiotika Komunikasi. Bandung : PT Remaja Rosdakarya

Sugiyono. 2009 . Memahami Penelitian Kualitatif. Jakarta : Alfabeta. 
Wahyu Wary Pintoko dan Diki Umbara. 2010. How To be A Cameramen. Yogyakarta : interbook

West, Richard dan Lynn H. Turner.2008. Pengantar Teori Komunikasi. Jakarta : Salemba Humanika.

http://www.khalidmustafa.info/2010/04/25/alangkah-lucunya-negeri-ini-sebuah-resensi.php

http://edukasi.kompasiana.com/2013/12/10/alangkah-lucunya-negeri-ini-615245.html

http://1hamsentok.blogspot.com/2013/05/analisis-film-alangkah-lucunya-negeri.html 